\title{
Treatment of recurrent urinary tract infections in a 60-year-old kidney transplant recipient - last- chance antibiotics and phage therapy
}

Olga Maria Rostkowska ( $\sim$ rostkowska.o@gmail.com )

Warszawski Uniwersytet Medyczny https://orcid.org/0000-0003-1652-6616

Ryszard Międzybrodzki

Phage Therapy Unit, Hirszfeld Institute of Immunology and Experimental Therapy, Polish Academy of

Sciences

\section{Dorota Miszewska-Szyszkowska}

Department of Transplantation Medicine, Nephrology and Internal Medicine, Medical University of Warsaw

\section{Andrzej Górski}

Phage Therapy Unit, Hirszfeld Institute of Immunology and Experimental Therapy, Polish Academy of Sciences

\section{Magdalena Durlik}

Department of Transplantation Medicine, Nephrology and Internal Medicine, Medical University of Warsaw

\section{Case report}

Keywords: kidney transplantation, antibiotics, antimicrobial resistance, bacteriophages, phage therapy, probiotics, microbiota

Posted Date: April 16th, 2020

DOI: https://doi.org/10.21203/rs.2.19287/v2

License: (1) (1) This work is licensed under a Creative Commons Attribution 4.0 International License. Read Full License 
The authors have withdrawn this preprint from Research Square 